\title{
nucture naturel
}

National Academic Journal of Architecture

\section{MUSEUM TRANSPORTASI AIR INDONESIA DI MAKASSAR DENGAN PENDEKATAN ARSITEKTUR KINETIK}

\author{
St. Aisyah Rahman1, Burhanuddin'2, Sulkifli Syam Saputra ${ }^{3}$ \\ Jurusan Arsitektur Fakultas Sains \& Teknologi UIN-Alauddin Makassar \\ E-mail: aisysipala@gmail.com, amin.burhanuddin@gmail.com, \\ sulkiflisyamsaputra.sss@gmailcom
}

\begin{abstract}
Abstrak - Transportasi air di Indonesia terutama di Makassar merupakan salah satu yang diandalkan untuk bepergian antar pulau. Sarana penunjang di Pelabuhan Makassar masih kurang sehingga masyarakat hanya memanfaatkan tempat yang tersedia untuk menunggu waktu keberangkatan sambil istrahat. Tujuan perancangan ini adalah untuk merancang museum transportasi air Indonesia di Makassar dan memperhatikan ketentuan yang terdapat pada arsitektur kinetik dari segi fasad bangunan yang mendasari perwujudan kebutuhan dan fungsi museum sebagai tempat informasi, edukasi, dan rekreasi. Hasil dari perancangan meninjau hal-hal teknis bangunan yaitu penentuan site atau lokasi, tata massa bangunan, kebutuhan dan hubungan ruang, sirkulasi ruang, sistem fasad bangunan, konsep bentuk (penentuan suasana pada interior bangunan), sistem struktur, utilitas, dan material bangunan, penggunaan sistem teknologi bangunan (secondary skin).
\end{abstract}

Kata kunci: Museum, Tranpotasi Air, Makassar, Arsitektur Kinetik.

\begin{abstract}
Water transportation Indonesia, especially in Makassar is one that is reliable to travel between islands. Supporting facilities in the port of Makassar still less so people just use the space that provided for waiting the departure time while resting. The purpose of this design is to design an Indonesian's Museum of water transportation in Makassar and play attention to the prorisions that found in Kinetic Architecture in building facade term based on the need realization and museum function as places of information, education, and recreation. The results of this design review the technical matters of the building is the by determination of the site or the location, layout of building mass, needs and relationships of space, circulation space, building facades system, the concept of form (determination of the atmosphere in the interior of the building), the structure system, utilities, and building materials, the use of building technology systems (secondary skin).
\end{abstract}

Keywords: Museum, Water Transportation, Makassar, Kinetic Architecture

${ }^{1}$ Dosen Jurusan Teknik Arsitektur UIN Alauddin Makassar

${ }^{2}$ Dosen Jurusan Teknik Arsitektur UIN Alauddin Makassar

${ }^{3}$ Alumni Jurusan Teknik Arsitektur UIN Alauddin Makassar Angkatan 2015 


\section{nucture nature}

National Academic Journal of Architecture

\section{PENDAHULUAN}

Transportasi air di Indonesia terutama di Makassar merupakan salah satu yang diandalkan untuk bepergian antar pulau. Sarana penunjang di Pelabuhan Makassar masih kurang sehingga masyarakat hanya memanfaatkan tempat yang tersedia untuk menunggu waktu keberangkatan sambil istrahat. Perlu sebuah sarana yang menunjang dari aktifitas masyarakat serta memberi pengetahuan kepada masyarakat mengenai sistem transportasi air yang ada di Indonesia baik yang bersifat tradisional maupun modern.

Museum transportasi air Indonesia di Makassar merupakan salah satu sarana yang akan menunjang aktivitas pelabuhan. Dengan adanya museum transportasi ini dapat memunculkan kearifan di tiap-tiap daerah misalnya museum ini akan memamerkan transportasi air kearifan lokal Sulawesi Selatan seperti kapal phinisi. Selain itu juga museum transportasi air ini akan memamerkan jenis kapal yang bersifat modern misalnya kapal penumpang dan lain-lain. Museum transportasi air ini akan memamerkan jenis koleksi berupa miniatur, foto-foto, dan ruangan penunjang yang akan ditambahkan pada bangunan. Untuk ukuran akan dipamerkan beberapa dari jenis transportasi air baik yang bersifat modern ataupun lokal sesuai dengan besaran ruang (Indoor) dan luas site pada bangunan (Outdor).

Menunjang aktivitas di Pelabuhan Makassar perlu sebuah tempat yang dapat memberikan kepada calon penumpang, masyarakat, dan para pelajar pengetahuan serta mengingat segala isi baik di langit maupun di bumi sebagaimana yang dijelaskan dalan Q.S Al-Baqarah/2:164.

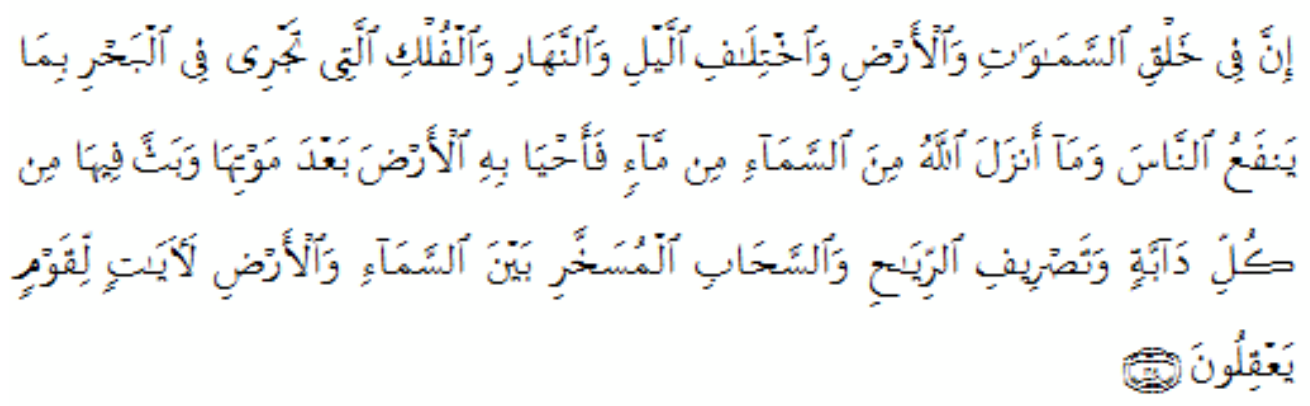

Terjemahan:

"Sesungguhnya dalam penciptaan langit dan bumi, silih bergantinya malam dan siang, bahtera yang berlayar di laut membawa apa yang berguna bagi manusia, dan apa yang Allah turunkan dari langit berupa air, lalu dengan air itu Dia hidupkan bumi sesudah mati (kering)-nya dan Dia sebarkan di bumi itu segala jenis hewan, dan pengisaran angin dan awan yang dikendalikan antara langit dan bumi; sungguh (terdapat) tanda-tanda (keesaan dan kebesaran Allah) bagi kaum yang memikirkan" (Q.S Al-Baqarah/ 2:164)

Pada ayat diatas dalam Tafsir Al-Misbah Jilid I hal.349-350, Quraish Shihab mengandung makna bahwa "manusia harus menunjukkan tentang bahtera-bahtera yang berlayar di Laut, membawa apa yang berguna bagi manusia. Ini mengisyaratkan sarana transportasi baik yang digunakan masa kini 


\section{nucture nature}

National Academic Journal of Architecture

dengan alat yang modern maupun masa lampau yang hanya mengandalkan angin dengan segala akibatnya.

Ayat di atas menjelaskan bahwa kapal-kapal sudah ada sejak lama dan perlu suatu wadah yang dapat mengingatkan dan memberi pengetahuan kepada masyarakat tentang tansportasi air. Museum merupakan salah satu wadah yang dapat menjawab akan kebutuhan masyarakat tersebut. Dengan adanya museum transportasi air Indonesia diharapkan merupakan usaha penyelamatan terhadap bukti-bukti sejarah dan pengenalan untuk masyarakat tentang transportasi yang ada di Indonesia terutama di Makassar. Dengan adanya museum transportasi ini diharapkan dapat menjadi tempat edukasi bagi pelajar, mahasisiwa, bahkan masyarakat yang ada di Makassar maupun di luar Kota Makassar.

Pada umumnya masyarakat masih memandang museum sebagai suatu tempat atau lembaga yang bersuasana statis, berpandangan konservatif atau kuno, mengurusi benda-benda kuno kalangan elite untuk kebanggaan dan kekaguman semata. Penerapan konsep Arsitektur Kinetik bertujuan mendapatkan fasad bangunan (eksterior) yang dapat berubah-ubah sehingga dapat menghilangkan kesan kekakuan. Sedangkan, fasad bangunan (interior) akan dirancang untuk mendapatkan kesan sesuai kondisi yang terdapat pada lokasi perancangan.

\section{BATASAN PEMBAHASAN}

Pembahasan diorientasikan pada faktor perancangan fisik museum transportasi air sesuai dengan arsitektur kinetik baik eksterior maupun interior bangunan, dengan memperhatikan jenis-jenis transportasi air yang akan dikoleksikan baik berupa miniatur, foto, dan ukuran sebenarnya.

\section{METODE PERANCANGAN}

1. Studi literatur, yaitu mengambil studi literatur dari buku-buku perpustakaan dan buku-buku lain yang berkaitan dengan judul untuk mendapatkan teori, spesifikasi, dan karakteristik serta aspekaspek arsitektural yang dapat dijadikan landasan dalam proses perancangan.

2. Studi preseden, yaitu mengambil studi preseden melalui internet Terhadap museum yang terdapat di Indonesia maupun luar negeri yang dibagi menjadi dua yakni; studi preseden sesuai dengan judul perancangan dan studi preseden sesuai pengaplikasian desain perancangan

3. Studi Lapangan, yaitu melakukan survei lapangan untuk mengetahui dan mengamati kondisi yang akan menunjang terhadap perancangan.

\section{LOKASI TAPAK}

Rencana Tata Ruang Wilayah Kota Makassar 2010-2030 menjelaskan bahwa lokasi perancangan museum transportasi air Indonesia di Makassar terletak di Pelabuhan Makassar (Pelabuhan SoekarnoHatta) kecamatan Wajo. Pemilihan tapak/site Museum Transportasi Air Indonesia di Makassar dengan Pendekatan Arsitektur Kinetik, didasarkan beberapa pertimbangan; ditinjau dari segi lokasi yang terletak di antara Pelabuhan Soekarno-Hatta, PT. Persero IV, dan PT. Bosowa Makassar. Sedangkan ditinjau dari segi geografis, lokasi berhadapan langsung dengan laut yang merupakan kelebihan dan kekurangan dalam proses perancangan. Selain itu Rencana Tata Ruang Wilayah (RTRW) kota 


\section{nucture nature}

National Academic Journal of Architecture

Makassar (2010-2030) mengatakan bahwa Pengembangan Kawasan Bangunan Umum pada kawasan pelabuhan terpadu ditargetkan menempati wilayah perencanaan seluas 26,24 Ha.

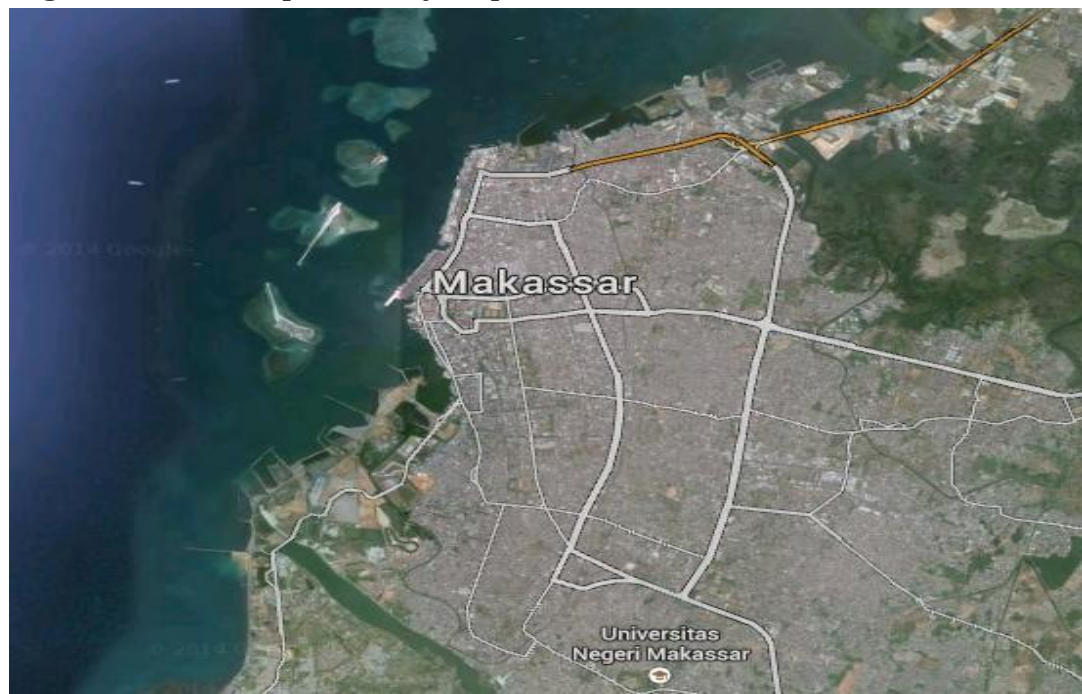

Gambar. Lokasi Perancangan, Pelabuhan Soekarno-Hatta

( Sumber: www.google.map.com, Desember 2014)

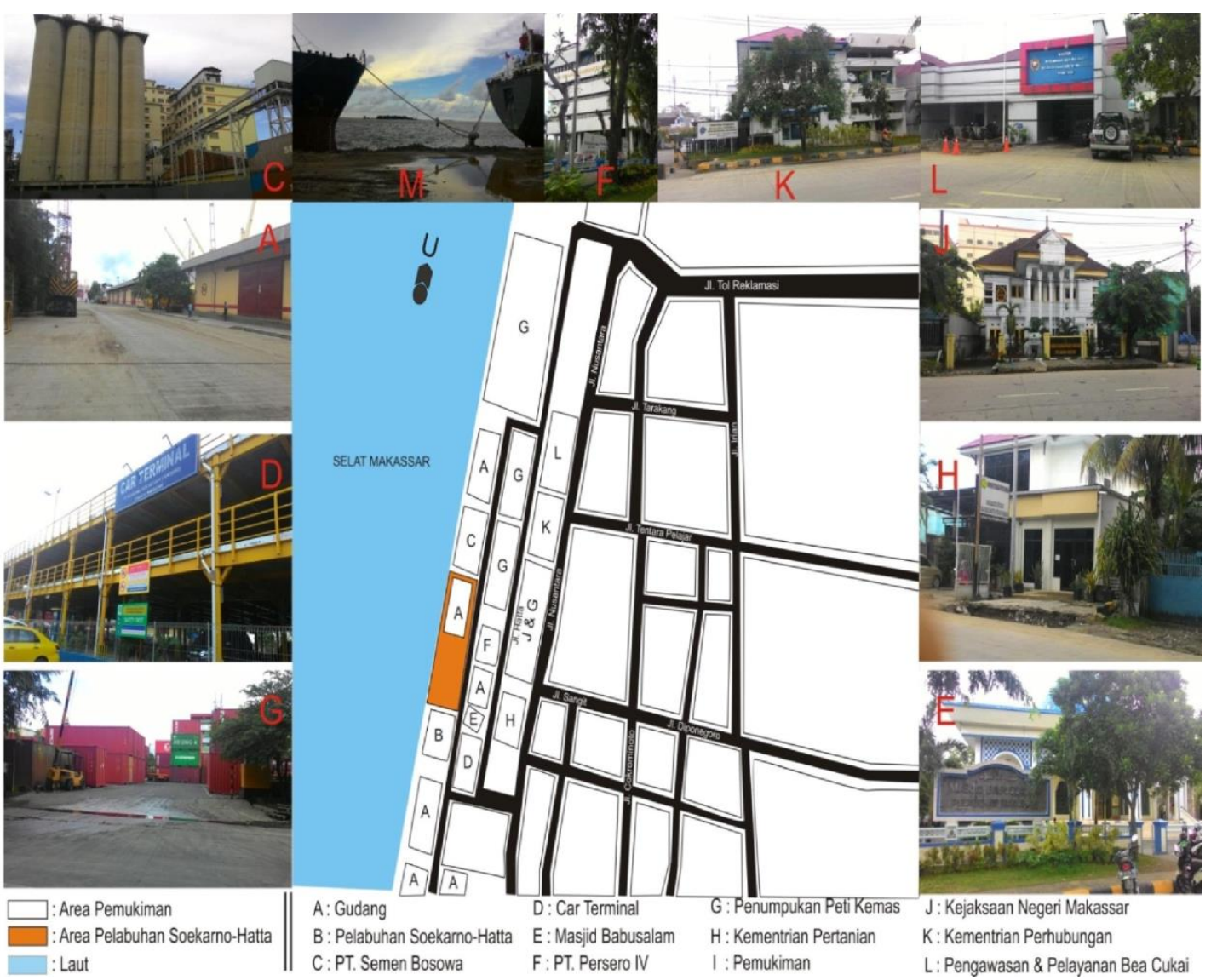

Gambar. Kondisi Lingkungan Perancangan, Pelabuhan Soekarno-Hatta 


\section{nucture naturel}

National Academic Journal of Architecture

\section{A. Pengolahan Tapak}

\section{HASIL PERANCANGAN}

1. Sirkulasi menuju tapak museum transportasi air dengan kendaraan dan berjalan kaki dapat ditempuh melalui gerbang 1 dan gerbang 2 pelabuhan soekarno-hatta. Pengunjung dari arah jl. hatta yang masuk ke area parkir dapat langsung masuk ke basement maupun ke museum utama. Sedangkan pengunjung dari pelabuhan soekarno hatta dapat langsung masuk ke museum utama melalui jembatan penghubung.

2. Setiap jembatan dan jalur pedestrian yang masuk ke bangunan disediakan jalur khusus untuk penyandang cacat. Perencanaan pada jalur penyandang cacat akan mempengaruhi standart kenyamanan sehingga dapat berfungsi dengan baik.

3. Rencana penzoningan pada museum transportasi air terbagi 3, yaitu zona publik, zona semipublik dan zona private. Zona publik (warna kuning) terdiri dari lahan parkir, ruang terbuka hijau dan ruang bersantai. Zona semi-publik (warna hijau tua) merupakan daerah untuk ruang - ruang administrasi maupun ruang menunggu. Sedangkan zona private (warna merah) merupakan area perkantoran. Area warna hijau muda merupakan area zona semi-publik dan semi private yang merupakan ruang control dan ruang pameran

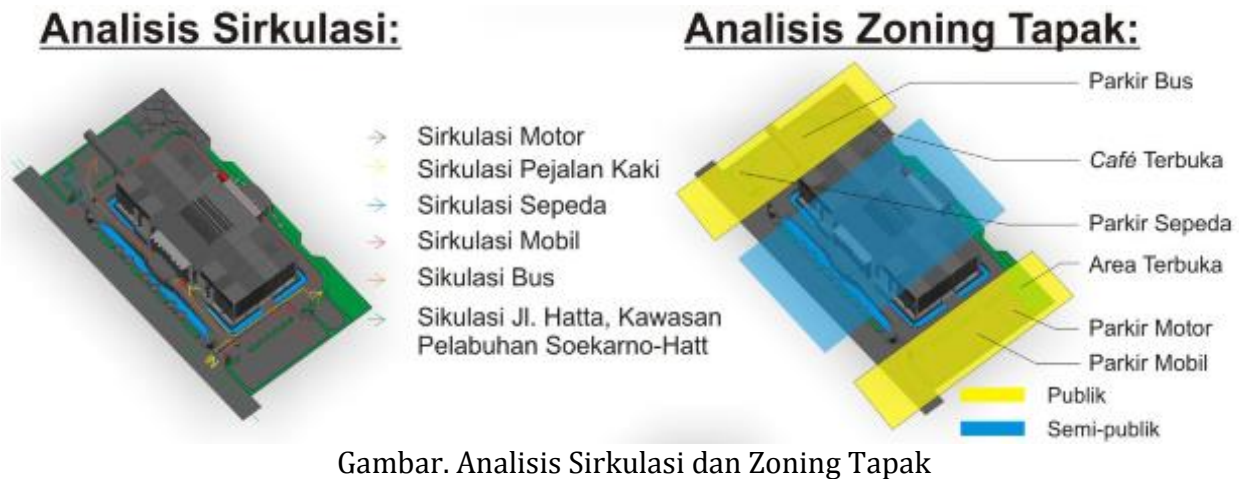

(Sumber : Hasil Desain, 21 November 2015)

4. Tingkat kebisingan tinggi terjadi saat kedatangan kapal penumpang yang bersandar pada pelabuhan dengan melakukan aktifitas seperti bongkar muat barang dan memuat calon penumpang. Adanya kondisi dari tapak maka perencanaan akan difokuskan menempatkan jenis vegetasi yang baik dan pemilihan material yang meredam suara. Pemilihan vegetasi dan material bangunan akan mempengaruhi bentuk dan kenyamanan bangunan 


\section{nucture \\ nature}

National Academic Journal of Architecture

\section{Analisis Kebisingan:}

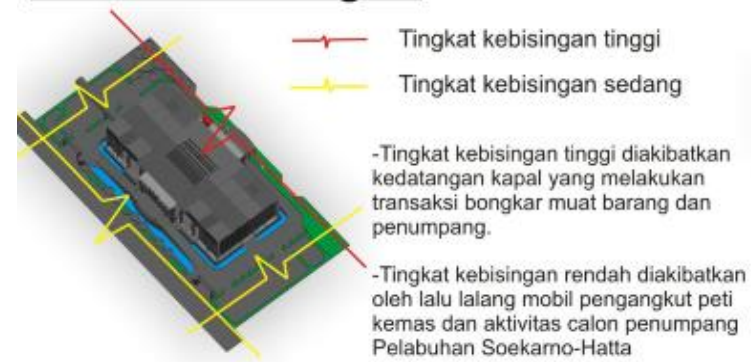

Analisis Arah Angin

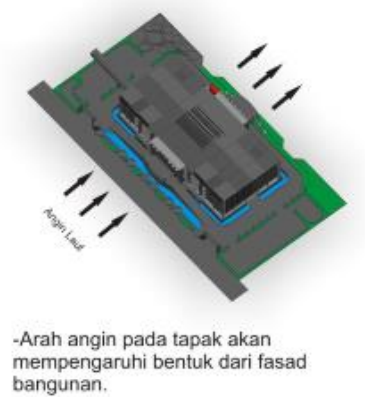

Gambar. Analisis Kebisingan dan arah Angin pada Tapak

(Sumber : Hasil Desain, 21 November 2015)

5. Penamambahan area terbuka baik taman dan cafe yang ditempatkan langsung di belakang bangunan atau berhadapan langsung dengan laut. Sehingga, pengunjung dapat bersantai sambil menikmati pemandangan laut. Adanya museum transportasi air ini diharapkan dapat menambah aktifitas untuk calon penumpang Pelabuhan Soekarno-Hatta. Penempatan jembatan yang menghubungkan museum dengan Pelabuhan Soekarno-Hatta sehingga calon penumpang tidak perlu keluar

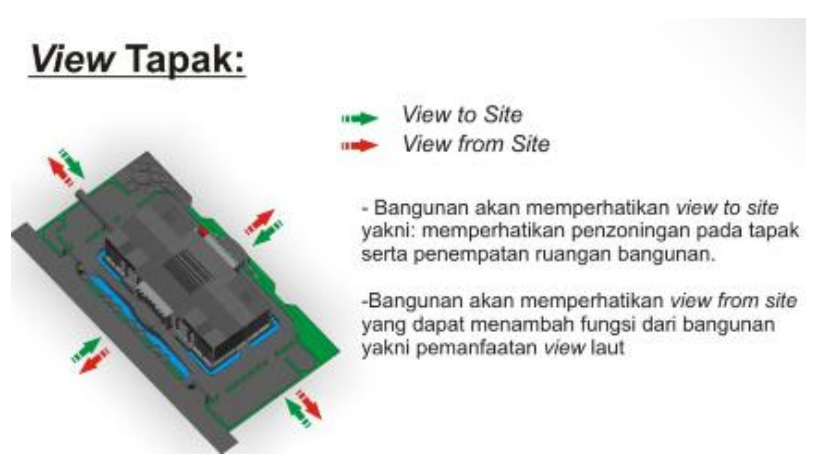

\section{Analisis Arah Matahari}

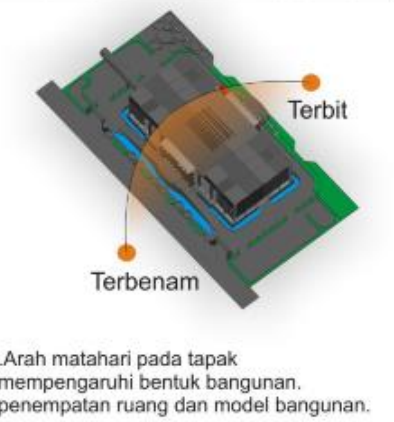

Gambar. Analisis View dan Arah Matahari pada Tapak

(Sumber : Hasil Desain, 21 November 2015)

\section{B. Konsep Bentuk}

Bentuk dasar persegi diambil dari pola tapak kemudian diaplikasikan dengan memperhatikan kondisi disekitar Pelabuhan Soekarno-Hatta. Bentuk persegi berdasarkan pengamatan sekeliling tapak yang difungsikan sebagai kawasan penyebrangan laut, baik barang maupun manusia (calon penumpang). Bentuk bangunan diekspos dari kontainer (peti kemas), bentuk kontainer juga mempengaruhi ide dari desain fasad. Pola fasad yang dapat bergerak diharapkan tidak menimbulkan kesan kaku dalam satu bentuk, penggunaan material yang tahan karat karena air laut sepeti fibrealum. Bentuk bangunan juga memperhatikan pola pergerakan matahari dan angin laut sehingga mempengaruhi bentuk dari fasad. Penggunaan sistem arsitektur kinetik pada fasad bagian utara dan selatan yang dapat bergerak dengan bantuan tenaga alami (angin). Sedangkan, fasad bagian timur dan barat dapat bergerak dengan tenaga listrik dan panel surya. Fasad bangunan bagian utara dan selatan mengacu pada bangunan Showroom kiefer technic. Penggunaan sistem arsitektur kinetik juga diaplikasikan pada atap bangunan yang dapat bergerak mengikuti arah matahari. 


\section{nucture do nature}

National Academic Journal of Architecture
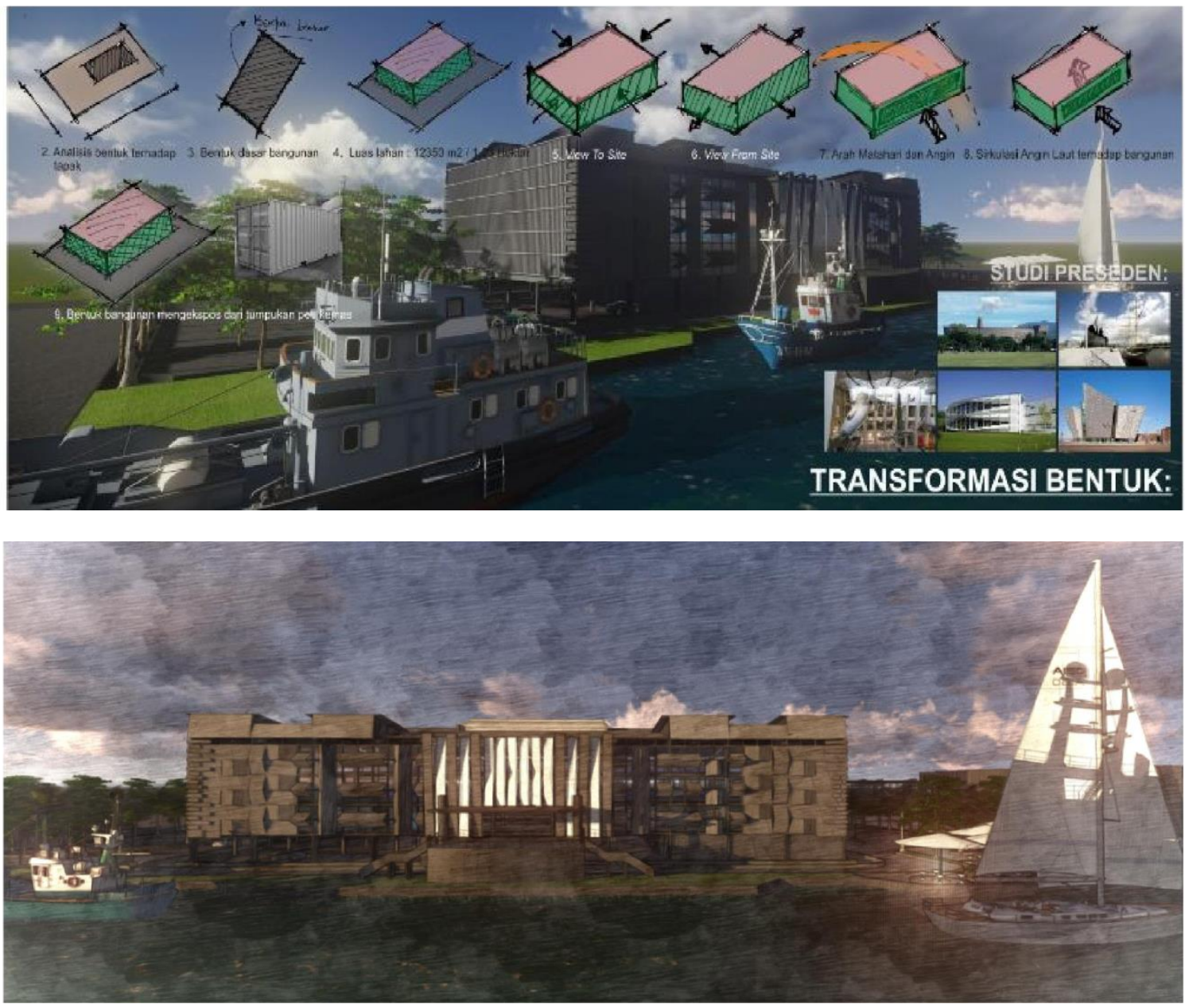

Gambar. Perpektif dari sudut pandang Pintu keluar

(Sumber : Hasil Desain, 21 November 2015)

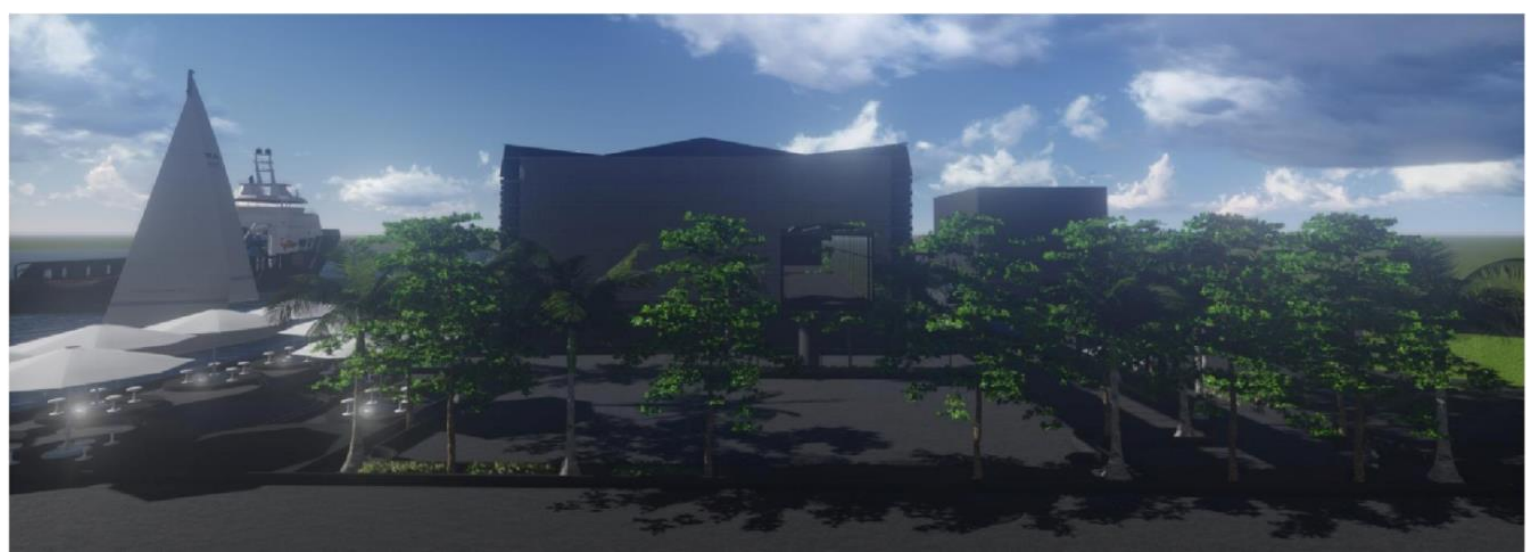

Gambar. Tampak Bangunan dari Arah Selatan

(Sumber : Hasil Desain, 21 November 2015) 


\section{nucture a nature}

National Academic Journal of Architecture

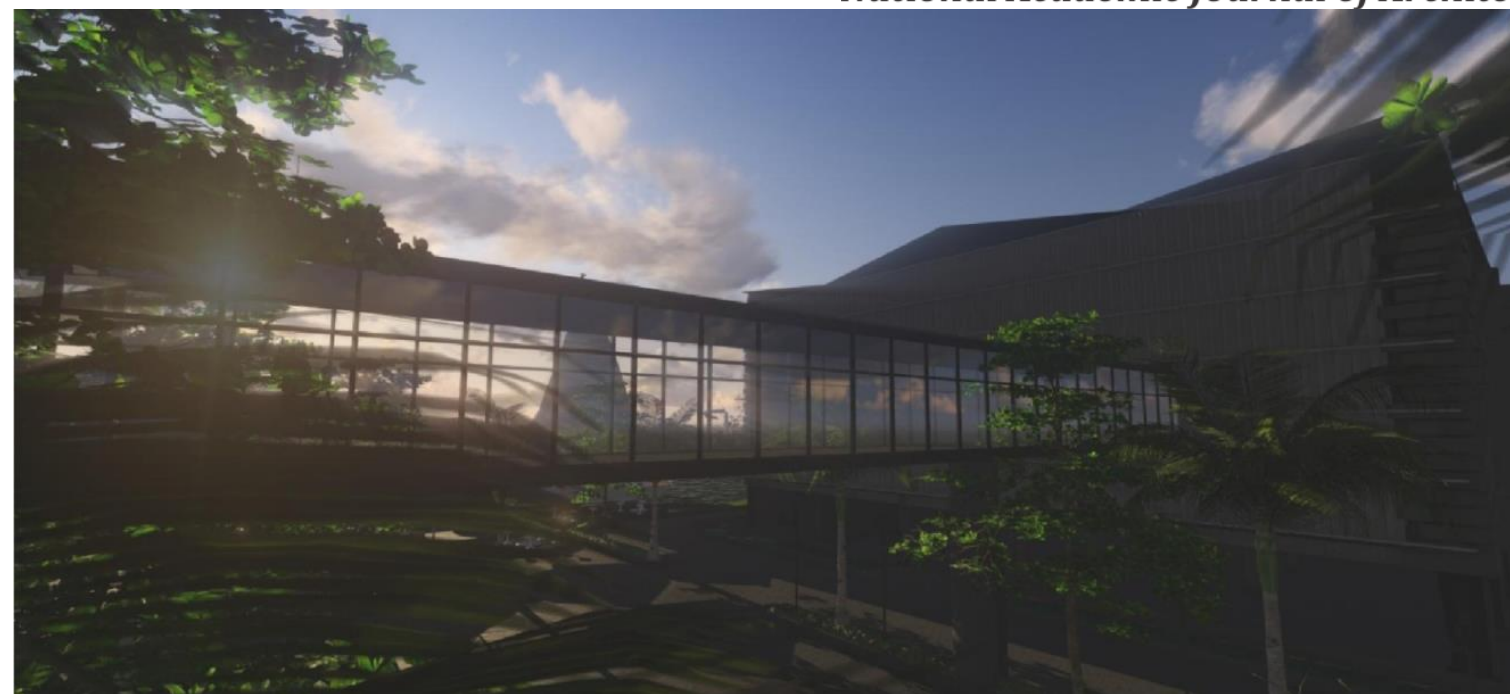

Gambar. Tampak Bangunan dari Sudut Pandang Jembatan Penghubung (Sumber : Hasil Desain, 21 November 2015)

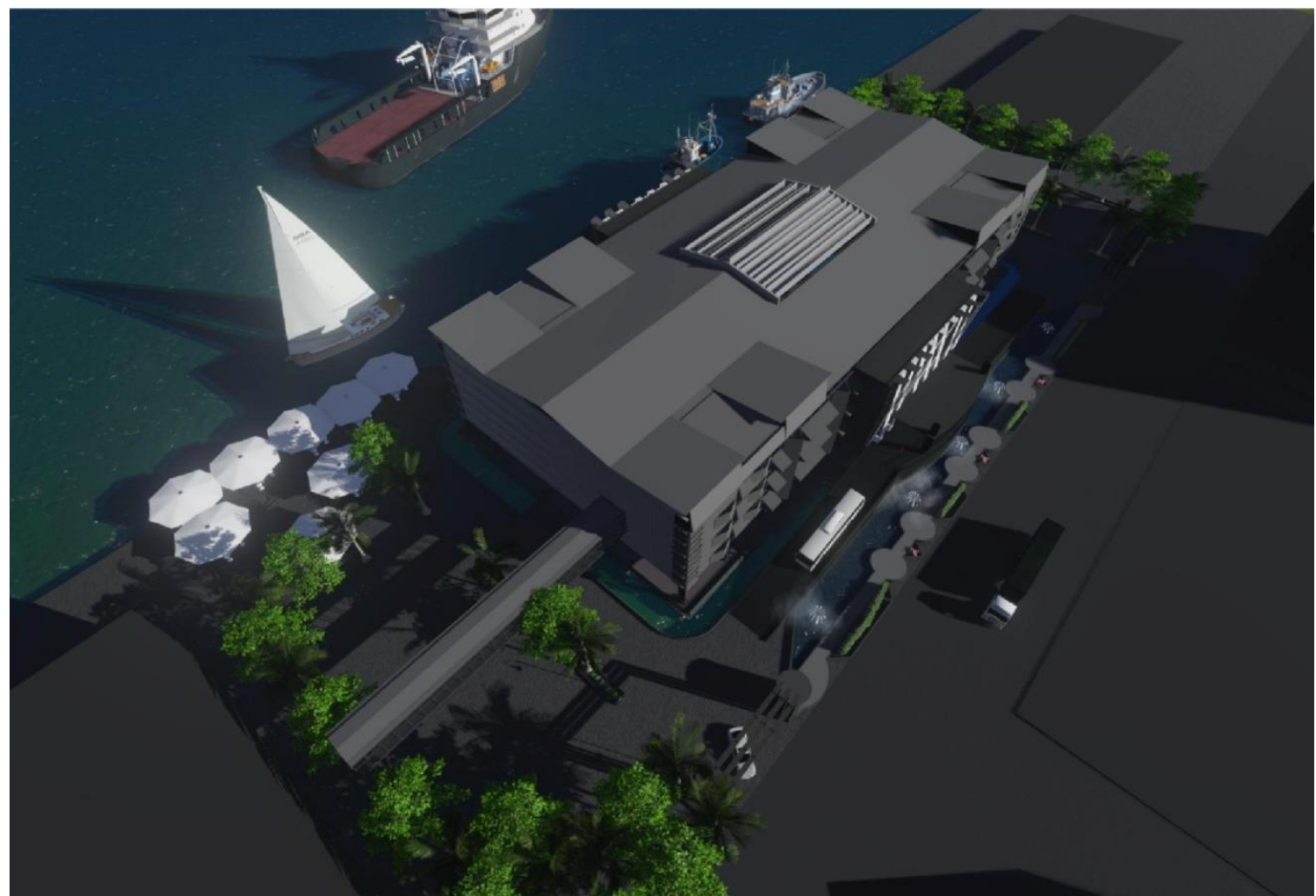

Gambar. Tampak Atas Museum Transportasi AIr

(Sumber : Hasil Desain, 21 November 2015) 


\section{nucture naturel}

National Academic Journal of Architecture

\section{Konsep Struktur, Material dan Double Façade}

Museum transportasi air menggunakan struktur bentang lebar (gable frame) dengan material baja wf yang kemudian dilapisi dengan cat anti karat (zincromat) dan steel pipa sebagai pengaku antar kolom . Selain itu, lantai dasar juga menggunakan kolom baja komposit $(60 \times 60 \mathrm{~cm})$. Kondisi landasan pada tapak museum yang merupakan daerah reklamasi pantai (cor beton dengan tiang pancang yang sudah ada). Sehingga museum hanya memerlukan plat sebagai pengganti pondasi untuk mengikat ke plat yang sudah ada.

Penggunaan material anti korosi mengingat letak museum yang berhadapan langsung dengan laut. Material pada atap menggunakan fibrealum dengan kelebihan tahan karat, tahan kimia dan cuaca (UV matahari dan kelembaban), ringan dan kuat, isolator panas dan listrik, serta pemasangan maupun perawatan mudah. Sedangkan, material untuk dinding atau fasad bangunan akan menggunakan polystyrene panel yang dikombinasikan dengan vapour barrier sehingga mampu meredam kebisingan.

Struktur lantai satu menggunakan cor beton dengan baja h-beam dan ricbdeck sebagai landasan. Sedangkan, lantai dua dan tiga menggunakan material kalsi dengan baha h-beam dan baja kanal c sebagai landasan.

\section{STRUKTUR DAN MATERIAL MUSEUM TRANSPORTASI AIR:}

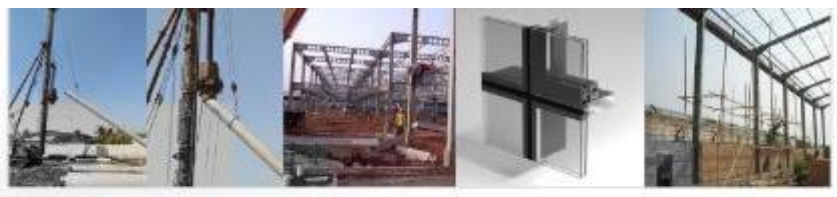

Struktur atap museum sebagian menggunakan sistem arsitektur kinetik untuk mendapatkan pencahayaan alam (skylight). Material atap yakni: fibrealum (tahan karat, kimia, tahan cuaca, isolato panas dan listrik, kebisingan rendah.

Struktur Kolom akan menggunakan sistem gable frame dengan baja wt freepabricasi $(800 \times 300 \mathrm{~cm}$, berat $210 \mathrm{~kg} / \mathrm{m})$ sebagal material utama dan pipa baja sebagai pengikat antar kolom (grid $800 \mathrm{~cm}$ )

Stuktur lantai pada museum yakni: tantai dasar menggunakan cor beton dengan tebal $20 \mathrm{~cm}$.

-lantai 1 menggunakan cor beton dengan tebal $20 \mathrm{~cm}$ dan ricdeck serta (400) $400 \mathrm{~cm}$ ) sebagai

-lantai 2 dan 3 menggunakan kalsi sebagai pijakan dan landasan dengan

menggunakan baja $\mathrm{H}$ dan kanal $\mathrm{C}$.

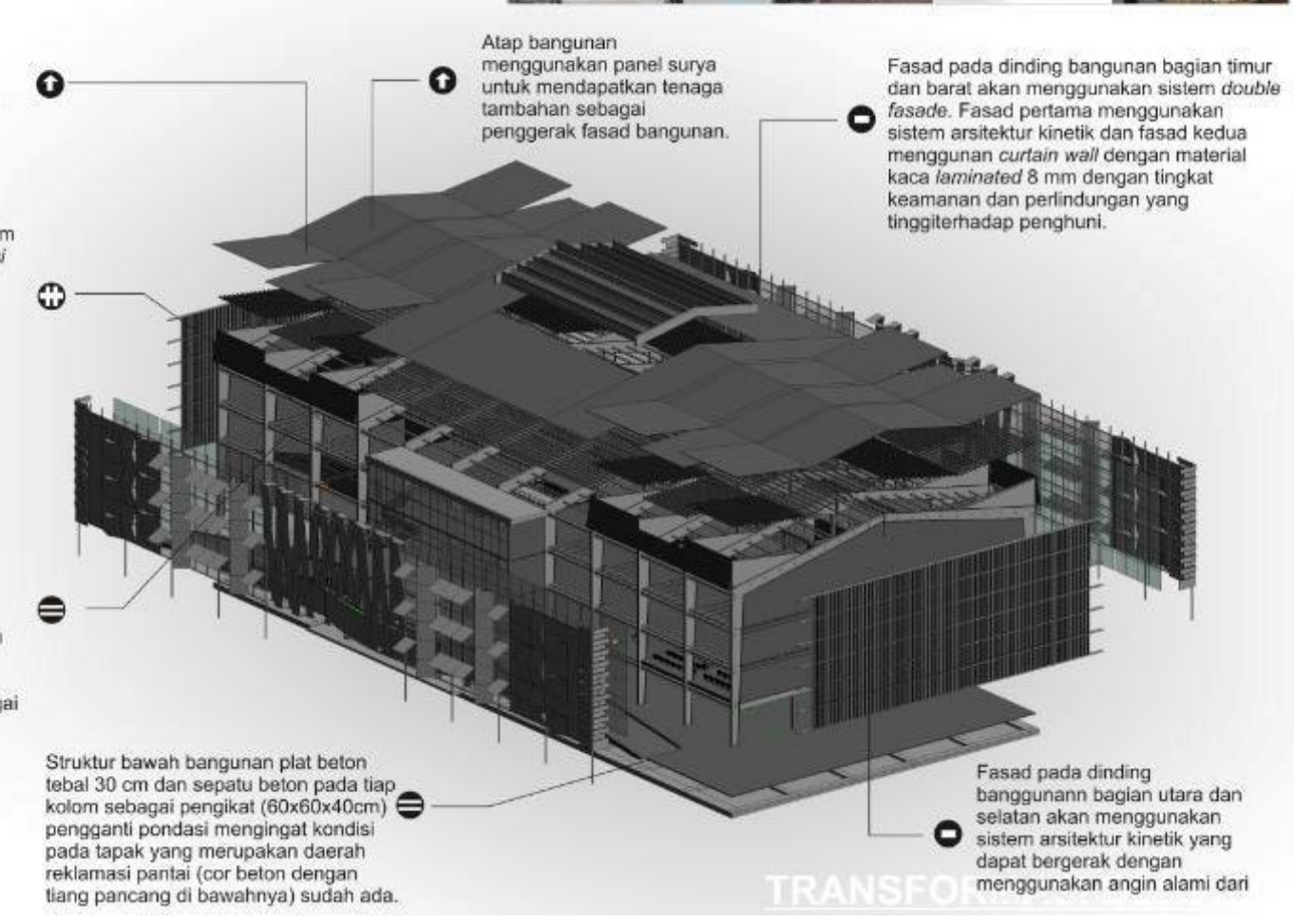

Gambar. Struktur Material

(Sumber : Olah Desain, 24 November 2015) 


\section{nucture nature}

National Academic Journal of Architecture

\section{Konsep Layout Ruang Dalam}

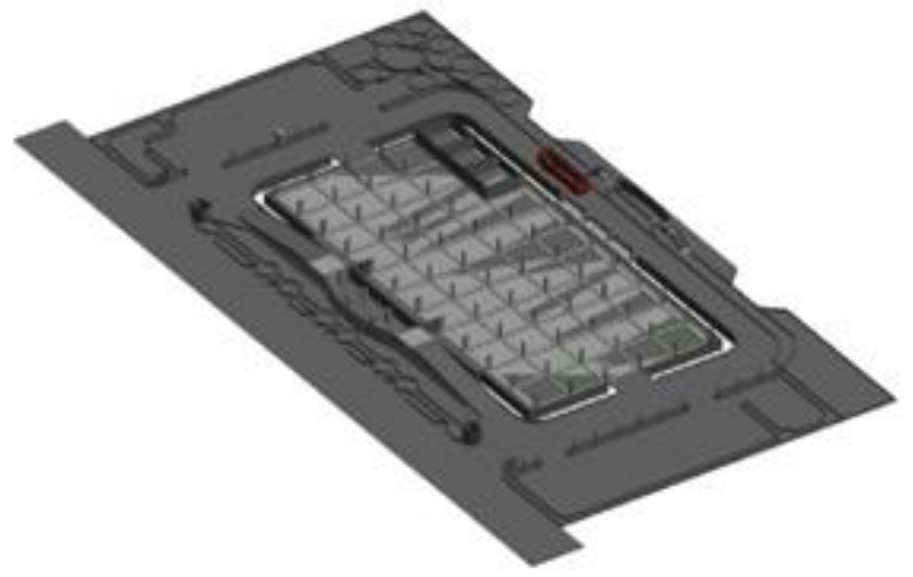
Ruangan:
1. Area Parkir
2. Ruang Cleaning
3. Service
4. Ruang ME
5. Ruang Kontrol

Gambar. Ruang dalam Lantai 1

(Sumber : Olah Desain, 21 November 2015)

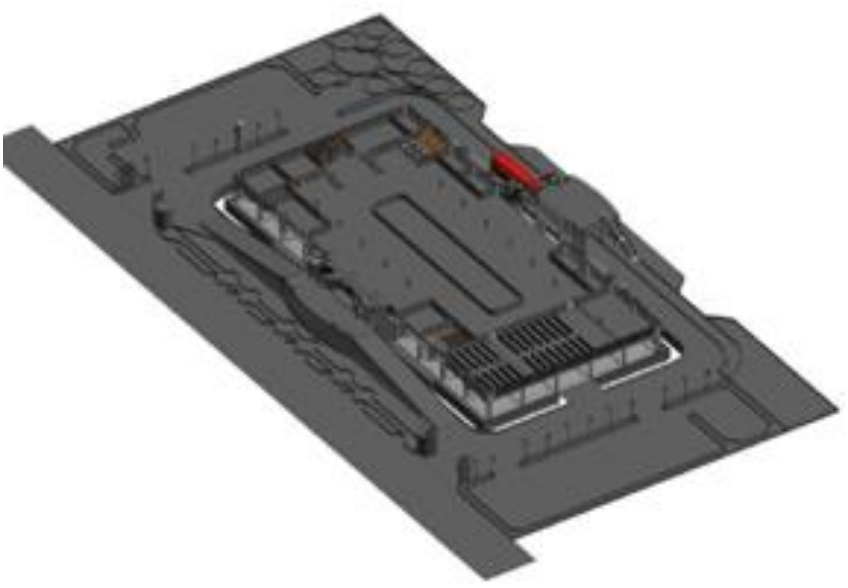

Gambar. Ruang dalam Lantai 2

(Sumber : Olah Desain, 20 November 2015)

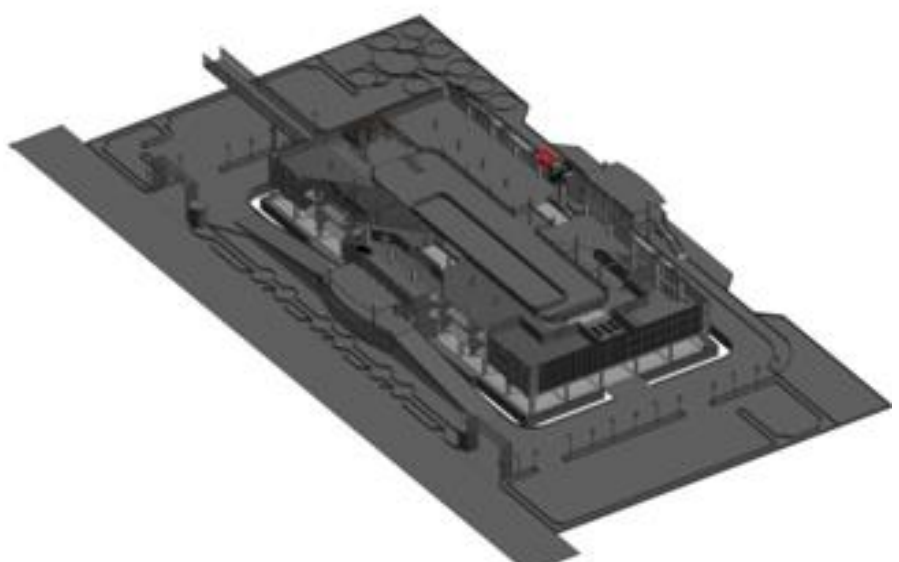

Gambar. Ruang dalam Lantai 3

(Sumber : Olah Desain, 20 November 2015)
Ruangan:

1. Loket

2. Hall

3. Ruang Administrasi

4. Ruang Cendramata

5. Poliklinik

6. Auditorium

7. R. Penyimpanan Bahan

8. R. Kontrol \& CCTV

9. Ruang Pameran

10. Ruang Keamanan

11. Lavatory Pria

12. Lavatory Wanita

13. Area Parkir

14. Ruang Cleaning

15. Service

16. Ruang ME

17. Ruang Kontrol

\section{Ruangan:}

1. Ruang Games Visual

2. Ruang Pameran Visual

3. Ruang Pameran

4. Lavatory Pria

5. Lavatory Wanita 


\section{nucture nature}

National Academic Journal of Architecture

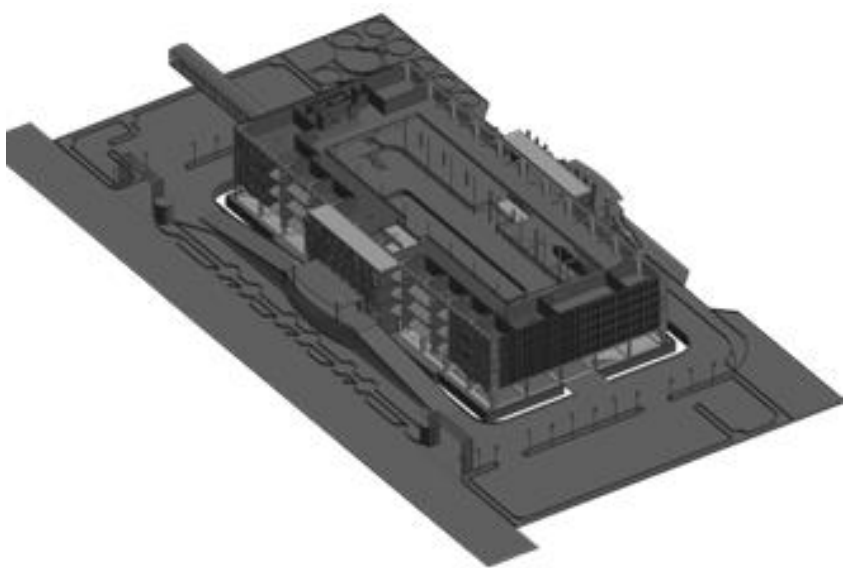

Gambar. Ruang dalam Lantai 4

(Sumber : Olah Desain, 20 November 2015)

$\begin{array}{ll}\text { Ruangan: } \\ \text { 1. } \\ \text { 2. } & \text { Ruang Staf Ahli Informasi } \\ \text { 3. } & \text { Ruang Sub Prombekalan } \\ \text { 4. } & \text { Ruang Arsip Data } \\ \text { 5. } & \text { Ruang Rapat } \\ \text { 6. } & \text { Ruang Sub Kepegawaian } \\ \text { 7. } & \text { Mushollah } \\ \text { 8. } & \text { Ruang Sub Service } \\ \text { 9. } & \text { Ruang Kepala Museum } \\ \text { 10. } & \text { Ruang Sekretaris } \\ \text { 11. } & \text { Lavatory Pria } \\ \text { 12. } & \text { Lavatory Wanita } \\ \text { 13. } & \text { Pantry }\end{array}$

\section{E. Konsep Arsitektur Kinetis}

1. Youssef Osama Elkhayat, (2014:816-845), interactive movement in kinetic architecture, vol.3 menagatakan bahwa beberapa konsep yang dimiliki oleh arsitektur kinetik yakni untuk beradaptasi dan berinteraksi dengan lingkungan sekitar (cahaya, suara, angin, dan manusia). Arsitektur telah melahirkan berbagai prinsip-prinsip desain bagaimana merancang dengan baik dan membangun lingkungan buatan di semua tingkatan. Aspek dan parameter yang perlu diperhatikan dalam mendesain bangunan bergerak atau arsitektur kinetik yakni: waktu, fisika, keseimbangan, kecepatan dan percepatan, bentuk dan pengulangan seri, massa dan berat, kompleksitas dan skala, dan interaksi.

2. Pemanfaatan sistem arsitektur kinetik pada atap bangunan akan memaksimalkan penggunaan cahaya matahari. Pada dinding bangunan juga menggunakan sistem arsitektur kinetik untuk memaksimalkan pecahayaan dan penghawaan alami. penggunaan kincir angin untuk pemanfaatan arah angin menjadi salah satu sumber energi. Penggunaan panel surya karena energi matahari menjadi pilihan energi yang banyak dipakai diseluruh dunia.

3. Penerapan sistem arsitektur kinetis diharapkan menjadi nilai lebih agar pengunjung dapat tertarik untuk mengunjungi museum. Selain itu, museum transportasi air menjadi salah satu contoh yang memberi kesan lebih menarik, tidak kaku, dan bernuansa modern seperti anggapan masyarakat selama ini.

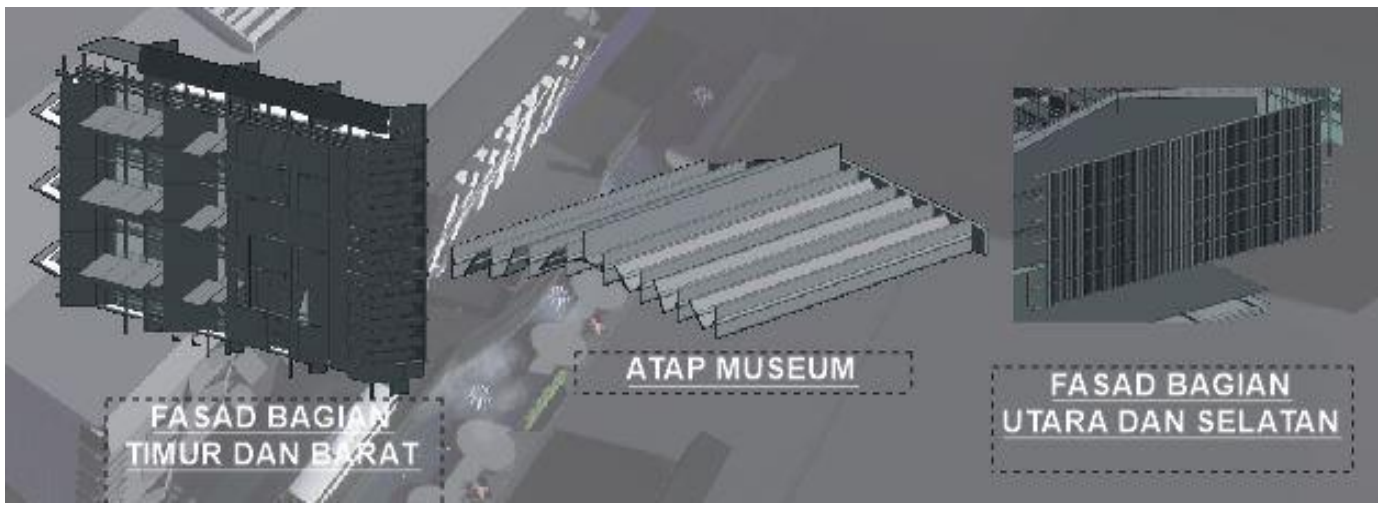

Gambar: Penerapan Sistem Arsitektur Kinetik

(Sumber : Olah Desain, 20 November 2015) 


\section{nucture naturel}

National Academic Journal of Architecture

\section{F. Konsep Utilitas Bangunan}

a. Untuk mencegah terjadinya bahaya kebakaran atau ledakan akibat petir, maka dibutuhkan sistem keamanan terhadap petir. Penangkal petir yang digunakan pada bangunan mengalirkan arus listrik dari petir yang menyambar ujung penangkal petir ke bumi (ground). Ada tiga bagian pada penangkal petir ini, yaitu ujung penangkal petir / tombak, kabel pengantar / down conductor dan grounding (tanah/bumi).

b. Sistem pengendalian keamanan yang digunakan adalah close circuit television (CCTV) yang terdiri dari monitor, kamera dan instalasinya. Sistem ini memerlukan ruang yang berfungsi sebagai pusat kontrol keamanan gedung. Kamera - kamera monitor di tempatkan pada daerah yang dianggap strategis.

c. Sistem fire protection (sistem pengindra api) merupakan sistem yang di desain untuk mendeteksi gejala kebakaran untuk memberi peringatan dalam sistem evakuasi dan ditindak lanjuti secara otomatis atau manual dengan sistem instalasi pemadam kebakaran. Sistem penangkal kebakaran disediakan di museum sebagai pencegah terjadinya kebakaran. Sistem yang digunakan terdiri dari sistem sprinkler, sistem hidran dan fire extinguisher.

d. Sistem transportasi dalam bangunan merupakan bagian yang sangat penting dalam membantu keamanan dan kenyamanan pengunjung. Sistem transportasi untuk perpindahan barang maupun pengunjung dilakukan secara vertikal dan horizontal. Sistem transportasi vertikal menggunakan eskalator sedangkan transportasi vertikal mengunakan jembatan penghubung.

e. Sistem pencahayaan dan penghawaan buatan menggunakan lampu yang berfungsi sebagai pengganti cahaya matahari. Lampu yang digunakan seperti lampu down light, lampu LED, lampu TL, lampu sorot LED lampu hias dan lampu jalan untuk area parkir dan plaza.

f. Penyediaan fasilitas plaza akan menambah aktifitas penunjang untuk yakni dengan menyediakan area terbuka untuk tempat istrahat atau rekreasi. Area parkir yang ditujukan untuk pengunjung museum maupun untuk bersantai.

g. Penyediaan sistem jaringan air bersih bersumber dari PDAM yang kemudian diendapkan dan disaring kemudian dialirkan ke bak penampung dan disalurkan ke bagian - bagian bangunan yang membutuhkan. Dalam memilih sumber baku air bersih, maka harus diperhatikan persyaratan yang meliputi kualitas, kuantitas, kontiunitas, dan biaya yang murah dalam proses pengambilan sampai proses pengolahannya. Beberapa sumber air baku yang dapat dipergunakan untuk penyediaan air bersih yakni : air hujan, air permukaan, air tanah, dan mata air

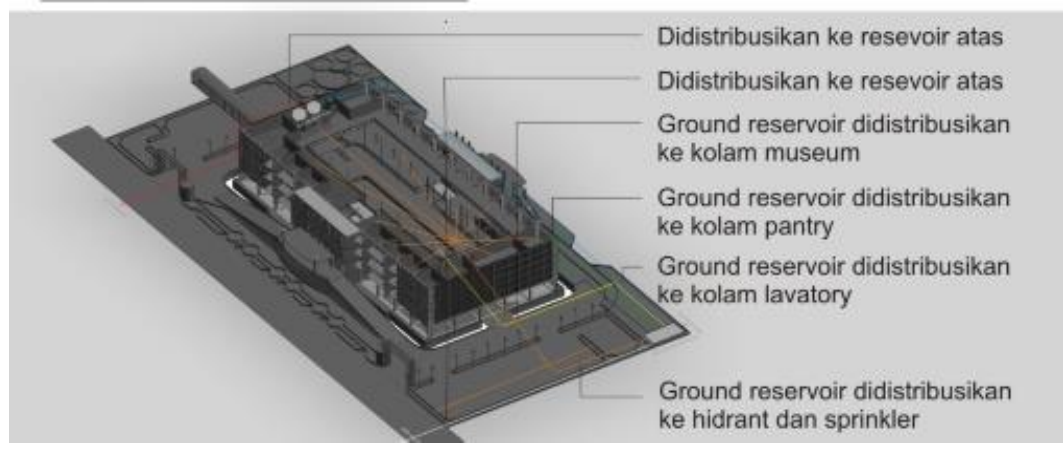

Gambar: Menejemen Air Bersih

(Sumber : Olah Desain, 20 November 2015)

h. Untuk jaringan air kotor dilakukan pemisahan dan dikumpulkan sesuai jenisnya kemudian dialirkan secara terpisah. Air yang berasal dari toilet dialirkan ke penampungan sementara kemudian kemudian ke penampungan utama dan di distribusikan ke drainase atau roil kota. 


\section{nucture nature}

National Academic Journal of Architecture

Penempatan area penampungan pada bangunan perlu diperhatikan untuk tidak mengurangi kenyamana bangunan.

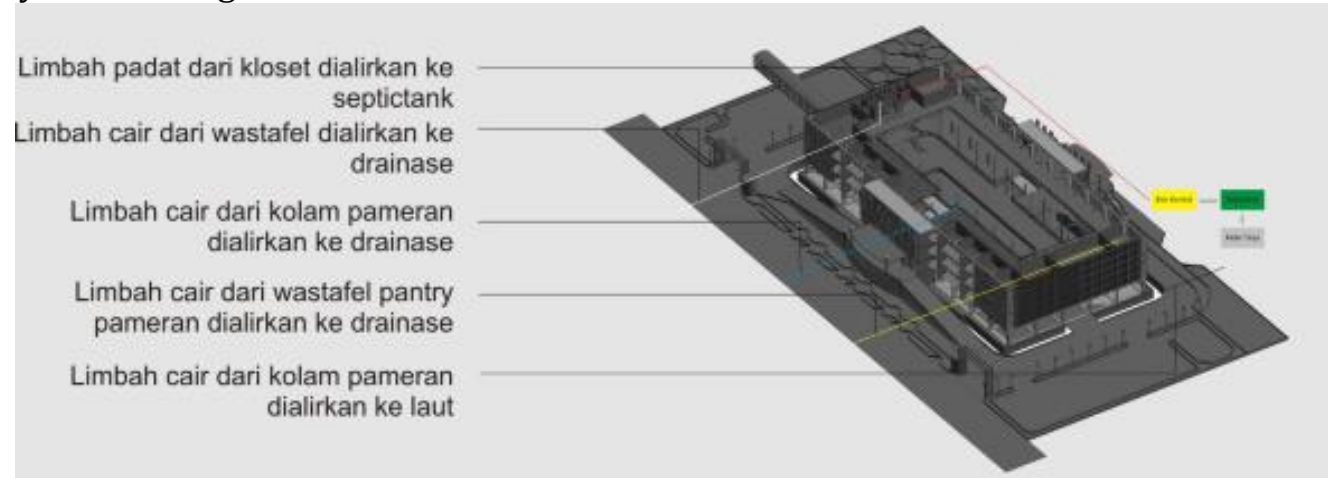

Gambar: Menejemen Air Kotor

(Sumber : Olah Desain, 20 November 2015)

\section{KESIMPULAN}

Museum Transportasi Air Indonesia di Makassar dengan Pendekatan Arsitektur Kinetik merupakan usaha penyelamatan terhadap bukti-bukti sejarah dan pengenalan untuk masyarakat tentang transportasi yang ada di Indonesia terutama di Makassar. Dengan adanya museum transportasi ini diharapkan dapat menjadi tempat edukasi bagi pelajar, mahasisiwa, bahkan masyarakat yang ada di Makassar maupun di luar Kota Makassar. Konsep Arsitektur Kinetis diterapkan pada atap bangunan yang dapat memaksimalkan penggunaan cahaya matahari. Pada dinding bangunan juga menggunakan sistem arsitektur kinetik untuk memaksimalkan pecahayaan dan penghawaan alami. penggunaan kincir angin untuk pemanfaatan arah angin menjadi salah satu sumber energi. Penggunaan panel surya karena energi matahari menjadi pilihan energi yang banyak dipakai diseluruh dunia. Selain itu perancangan ini juga meninjau hal-hal spesifik dari perancangan bangunan yaitu penentuan site atau lokasi, tata massa bangunan, kebutuhan dan hubungan ruang, sirkulasi ruang, sistem fasad bangunan, konsep bentuk (penentuan suasana pada interior bangunan), sistem struktur, utilitas, dan material bangunan, penggunaan sistem teknologi bangunan (secondary skin). 


\section{nucture nature}

National Academic Journal of Architecture

\section{DAFTAR PUSTAKA}

ARG- Isaac. 1986. Pendekatan Kepada Perancangan Arsitektur. Bandung : Intermata

Belia, Anes., Solikhah, Ely. 2010. Analisa Alun Alun Kota Tegal 2. Diploma Desain Arsitektur: UNDIP (Tidak dipublikasikan).

Callender, John Hancock and Joseph de Chiara, Time Saver Standard For Building Types, Mc Graw Hill, Inc, New York, 1973

Chaerwansyah,Bany dan Riany,Meta (2014) judul Itenas. Jurnal Arsitektur Itenas volume 4

D.K. Ching;; 1990. Pengantar Perancangan Ruang; terjemahan Edwart Hutabarat; Jakarta: PT. Gramedia Pustaka Utama

D.K. Ching, Francis. 1973. Arsitektur Bentuk, Ruang dan Susunannya, Jakarta: Erlangga.

D.K. Ching, dan Adams, Cassandra, Francis, 2003, Building Construction Illustrated/Third Edition: terjemahan John Wiley dan Sons: Erlangga.

Edward T. White; 1985. Analisis Tapak Pembuatan Diagram Informasi Bagi Perancangan Arsitektur, Intermedia, Bandung,

Edward T. White; 1985. Buku Sumber Konsep, Intermedia, Bandung

Ensiklopedi Nasional Indonesia, Jilid VII, (Jakarta: Cipta Adi Pusaka, 1989), hlm. 74-75.

Enviromental Sustainability, 2006, Campus Energy Conservation and Green Building Practices Bowling Green State University Office of Design and Construction.pdf.

Heinz frick, Dasar-dasar pembangunan berkelanjutan dan ramah lingkungan. Heinz frick, konsep arsitektur ekologis di iklim tropis.

Haris, Cryill M. 1975. Dictionary of Architecture and Construction. New York: McGraw-Hill Company.

Kamus Besar Bahasa Indonesia, Depdikbud,

Kustianingrum Dwi, Salahuddin Fikri, Yusuf Anas, Mulyana Anthony (2012), Laporan Penelitian, Kajian tatanan massa dan bentuk bangunan terhadap konsep ekologi di Griyo Tawang, Solo, hlm. 8-12.

Moloney, Jules,: (2011). Designing Kinetics for Architectural Facades. This edition published in the Taylor \& Francis e-Library, 2011.

Ned Kahn Studios, Angin Arbor, www.n edkahn.com (A ccessed: 28 7, 2013). Neufert,Ernest: 2002:120. Data Arsitek Jilid 2. Jakarta: Erlangga.

Neufert,Ernest; 1997. Data Arsitek Jilid 1. Jakarta: Erlangga. Bany Chaerwansyah, dkk

Neufert,Ernest. Architect's Data. Second. Dialihbahasakan oleh Sjamsu Amril. Jakarta: Erlangga, 1991.

Prabawasari, V.W., Suparman, Agus. 2008. Tata Ruang Luar. Jakarta: Gunadharma.

Poerwadarminta, WJS. Kamus Umum Bahasa Indonesia edisi ketiga. Jakarta: Balai 1988.

Shihab, Quraish, Jilid 1, hal.349-350, Tafsir Al-Misbah Shihab, Quraish, Jilid 7, hal.145, Tafsir Al-Misbah Shihab, Quraish, Jilid 9, hal.149, Tafsir Al-Misbah

Sugono, Dendy. 2008. Kamus Besar Bahasa Indonesia. Jakarta: Pusat Bahasa Depdiknas

Sutaarga, Amir, A, 1971, Persoalan Museum di Indonesia, Direktorat Ditjen Kebudayaan Departement P dan K, Cetakan III, Jakarta

Tofani, Logi. 2011,: Laporan Tugas Akhir, Terminal Imbanagara Kabupaten Ciamis. Fakultas Teknik dan Ilmu Komputer, Universitas Komputer Indonesia.

Yadnya, Dharma. 2012. Konsep Perancangan Tapak. Disampaikan dalam Perkuliahan Teori \& Metode Perancangan Arsitektur 2. Denpasar: Tidak diterbitkan.

W.F. Wetheim, Indonesian Society in Transition: A Study of Social Change (The hague: W. van Hoeve , 1969), hlm. 16-37. Lihat juga A.S. Walcott, Java and her Neighbors: A traveler's Note in Java, Celebes, the Moluccas and Sumatra, (New York and London: Knickerbocker Press, 1914), hlm. 1; "Koninklijke Paketvaart Maatschappij”, KPM: Official Yearbook 1837-1938, (Batavia: De Unie, 1938), hlm. 37; S. Ali, 'Inter-island Shipping', Bulletin of Indonesian Economic Studies 3, 1966, hlm. 27.

\section{WEBSITE:}

Badan Pusat Statistik Kota Makassar. (2013). Makassar Dalam Angka 2013, diakses pada tanggal 28 Mei 2013. Sumber:

http://makassarkota.bps.go.id/

Hutagalung, Dedek. 2010. Pengertian Ruang. Diakses pada 12 April 2014.http://dedekbaskom.blogspot.com/2010/06/ruang.html http://id.scribd.com/doc/207669608/Klasifikasi-Museum http://id.scribd.com/doc/36500199/Arti-Dan-Fungsi-Museum

http://kebudayaan.kemdikbud.go.id/bpcbaceh/2014/02/07/museum-tsunami-aceh-merupakan-lokasi-wisata

http://www.archdaily.com/223483/titanic-belfast-civic-arts-todd-architects/

http://wayang.wordpress.com/2010/03/06/daftar-museum-di-indonesia/

(http://www.indoenergi.com/2012/04/keunggulan-dan-kelemahan-panel- surya.html)

M . Fox, saya nteractive arsitektur 2012, http : // www . robotecture . com /

Rahmah, Nadiya. 2010. Sistem Sirkulasi Tapak: Nadra's Note. Diakses pada 10April 2014. http://nadrasnote.blogspot.com/2010/04/sistem-sirkulasi- tapak.html

Sofyan, Deden Asep. 2010. Jenis-jenis Sirkulasi. Diakses pada 8 April 2014. http://dedenasepsofyan.blogspot.com/2010/02/jenis-jenis-polasirkulasi.html

showcase/ interactive - arsitektur-book-2009 / (Diakses: 1023 2013)

www.bimbingan.org/fungsi-museum-di-indonesia.htm www:museumku.wordpress.com/peranan-museum-bagi-masyarakat-masa-kini

Ashihara, Yoshinobu. 1981. Exterior Design in Architecture. New York: Van

Nostrand Reinhold. 